\title{
ANALISIS PERBANDINGAN BRAND EQUITY PRODUK OLAHRAGA MEREK NIKE DENGAN MEREK ADIDAS
}

\author{
Ni Kadek Ayu Juniantari ${ }^{1}$ \\ Eka Sulistyawati ${ }^{2}$ \\ ${ }^{1,2}$ Fakultas Ekonomi dan Bisnis Universitas Udayana (Unud), Bali, Indonesia \\ email: tarijun@yahoo.co.id
}

\begin{abstract}
ABSTRAK
Penelitian ini bertujuan untuk mengetahui adanya perbedaan brand equity pada produk olahraga merek Nike dengan merek Adidas dari persepsi atau sudut pandang atlet Kota Denpasar. Populasi pada penelitian ini adalah seluruh atlet Kota denpasar yang menggunakan produk olahraga merek Nike dengan merek Adidas untuk menunjang kegiatan latihan. Jumlah sampel yang digunakan dalam penelitian ini adalah sebanyak 100 responden dengan menggunakan metode purposive sampling dan teknik analisis data menggunakan Analisis Deskriptif dan Uji Beda T-test. Berdasarkan hasil penelitian dapat diketahui bahwa terdapat perbedaan kesadaran merek (brand awareness), asosiasi merek (brand association),persepsi kualitas (perceived quality), dan loyalitas merek (brand loyalty) antara produk olahraga merek Nike dengan merek Adidas.

Kata kunci : perbandingan, merek, brand equity, brand awareness, brand association, perceived quality, brand loyalty
\end{abstract}

\footnotetext{
ABSTRACT

This study aims to determine brand equity differences between Nike and Adidas from Denpasar athletes perception. The population in this study are all athletes in Denpasar who use the sport product brand Nike and Adidas to support training activities. The sample that used in this study is 100 respondents using Purposive Sampling method, and the data analysis technique used is Descriptive Analysis and T-test technique. Based on the research result, it shows that there are differences in brand awareness, brand association, perceived quality, and brand loyalty between Nike and Adidas sport product.

Keywords : comparison, brand, brand equity, brand awareness, brand association, perceived quality, brand loyalty
} 


\section{PENDAHULUAN}

Olahraga adalah salah satu bagian penting dalam kehidupan. Olahraga saat ini tidak hanya dijadikan kegiatan yang berorientasi pada faktor fisik saja, namun juga sebagai ajang memperoleh prestasi (Mirhan \& Jusuf, 2016). Olahraga berperan sebagai media pembangun spirit kebangsaan serta alat pemersatu bangsa (Utami, 2015). Di dunia internasional, olahraga dikatakan sebagai budaya karena keragaman sosial budaya dan kondisi geografis antar negara satu dengan negara lain yang berbeda menyebabkan keanekaragaman cabang olahraga (Alam et al., 2016)

Tak jarang pesta olahraga dijadikan sebagai ajang untuk mempromosikan negara masing-masing. Begitu pula dengan olahraga di Indonesia, pemerintah selalu menargetkan hasil tinggi di setiap pesta olahraga setingkat Sea Games, Asian Games dan Olimpiade. Untuk mewujudkan cita-cita ini maka diperlukan program peningkatan prestasi yang memerlukan sarana dan prasarana serta pembinaan sejak usia dini. Hal ini dapat terwujud apabila kegiatan pembinaan dan pelatihan dilaksanakan secara terpola dan terarah sehingga mampu menjadi salah satu aset negara dimasa mendatang.

Proses pembinaan olahraga ini harus dilakukan secara terus menerus dan berkesinambungan guna memperbaiki kondisi pencapaian prestasi olahraga Indonesia yang secara umum menunjukkan inkonsistensi. Dimulai dari pembinaan atlet-atlet daerah, pembinaan dilakukan di pusat-pusat pelatihan atlet atau klub olahraga (Utami, 2015).

Dengan total 34 provinsi di Indonesia maka Indonesia berpotensi besar menghasilkan regenerasi atlet dengan cepat. Bali merupakan salah satu provinsi dengan jumlah atlet potensial yang cukup besar terbukti dengan jumlah atlet yang berlaga pada Pekan Olahraga Provinsi Bali Tahun 2017 lalu diikuti sebanyak 4.353 atlet. Jumlah ini mengalami peningkatan dari dua tahun sebelumnya yang diikuti sebanyak 3.773 atlet

Tabel 1.

Data Jumlah Atlet Pekan Olahraga Provinsi Bali 2017

\begin{tabular}{cc}
\hline Kontingen & Jumlah Atlet \\
\hline Denpasar & 771 \\
Badung & 710 \\
Buleleng & 640 \\
Gianyar & 510 \\
Tabanan & 421 \\
Jembrana & 341 \\
Karangasem & 323 \\
Bangli & 322 \\
Klungkung & 315 \\
\hline
\end{tabular}

Sumber : www.nusabali.com, 2017

Tabel 1. merupakan data jumlah atlet masing-masing kabupaten yang mengikuti Pekan Olahraga Provinsi Bali Tahun 2017. Denpasar sebagai ibukota Provinsi Bali mengirimkan sebanyak 771 atlet sekaligus menjadi kontingen dengan jumlah peserta terbanyak dibandingkan kontingen kabupaten lain Jumlah atlet Denpasar yang terbilang besar ini membuat kebutuhan akan produk olahraga 
yang diperlukan untuk menunjang kegiatan latihan menjadi meningkat (Silaban \& Marselia, 2016).

Adanya permintaan yang tinggi terhadap perlengkapan olahraga di Kota Denpasar akan memunculkan peluang bagi perusahaan multinasional yang mencoba menguasai pasar dalam kategori produk olahraga. Produk sejenis dapat dihasilkan oleh perusahaan yang berbeda karena produsen masih melihat peluang pasar yang dapat diraih walaupun produk sejenis telah hadir sebelumnya. Karena itu produk sejenis perlu menciptakan keunggulan sebagai daya saing untuk mempertahankan keberadaannya di pasar dan di mata konsumen (Sigiro dkk., 2016).

Maka dari itu dibutuhkan sesuatu yang dapat merangsang konsumen, salah satunya dengan menonjolkan sesuatu yang berbeda dari sebuah produk melalui daya saing merek agar konsumen dapat melihat keunikan produk tersebut walaupun banyak produk yang sejenis (Nainggolan, 2018). Peran merek dianggap penting karena dapat memberikan keunggulan bersaing dan merupakan salah satu cara agar bias menang dalam persaingan (Silaban \& Marselia, 2016). Peranan penting yang dimiliki merek adalah dapat mempersatukan harapan konsumen pada saat produk memberikan janji pada konsumen (Chen \& Green, 2012).

Produk dengan tampilan yang indah dan menawan akan mudah menarik konsumen namun faktor merek justru yang sangat mempengaruhi produsen dalam memasarkan produk tersebut (Idris dkk., 2015). Untuk dapat bertahan di pasar yang kompetitif diperlukan suatu merek yang dapat menciptakan nilai tambah produknya. Dengan ketatnya persaingan membuat perusahaan harus menciptakan sesuatu yang bisa tertanam dengan mudah dibenak konsumen (Dewi, 2017).

Salah satu aset untuk mencapai keadaan tersebut adalah dengan menciptakan merek (Huang et al., 2014). Garlina (2014) menyatakan bahwa merek juga memiliki nilai yang tinggi, nilai prestasi yang baik, dan memiliki brand equity yang besar. Merek yang memberikan nilai tambah lebih tinggi akan selalu menjadi pilihan konsumen (Darmawan \& Syarifah, 2016). Merek yang sukses memberikan keunggulan kompetitif yang penting bagi perusahaan (Fayrene \& Lee, 2011). Merek yang kuat sudah pasti dapat menguasai pasar, karena kekuatan merek merupakan salah satu aset perusahaan berharga, yang dapat digunakan untuk memprediksikan kelangsungan hidup perusahaan (Shabbir \& Jing, 2014). Pada intinya, perusahaan dengan brand equity yang tinggi akan mendapatkan keunggulan kompetitif dan menikmati peluang untuk memperluas kesuksesan, meningkatkan ketahanan terhadap tekanan promosi pesaing, serta menciptakan penghalang bagi kompetitor untuk masuk dalam pasar (Severi \& Ling, 2013).

Berikut adalah data dari Top Brand Award pada Tahun 2017, mengenai market share produk olahraga di Indonesia yang disediakan oleh website Top Brand Award dari setiap kategori produk olahraga. Data ini dapat menunjukan produk-produk olahraga mana saja yang berada dalam kondisi baik dalam persaingan sehingga mampu menguasai market share pada Tahun 2017. 
Tabel 2.

Top Brand Index 2017 Fase 2 Kategori : Peralatan Olahraga

\begin{tabular}{lllll}
\hline \multirow{2}{*}{ Nama Merek } & \multicolumn{5}{c}{ Kategori Produk } \\
\cline { 2 - 5 } & $\begin{array}{c}\text { Tas Olahraga } \\
(\%)\end{array}$ & $\begin{array}{c}\text { Pakaian Renang } \\
\text { (\%) }\end{array}$ & $\begin{array}{c}\text { Pakaian } \\
\text { Olahraga (\%) }\end{array}$ & $\begin{array}{c}\text { Sepatu } \\
\text { Olahraga (\%) }\end{array}$ \\
\hline Adidas & 45,7 & 3,2 & 54,3 & 38,2 \\
Nike & 25,5 & 6,1 & 26,4 & 32,2 \\
Puma & 5,3 & 5,4 & 5,4 & 3,6 \\
Converse & 2,7 & & 2,1 & 3,3 \\
Diadora & 2,4 & 27,8 & & 3,3 \\
Eagle & & & 1,3 & \\
Reebok & & & & \\
Yonex & & 22,3 & & \\
Speedo & & & &
\end{tabular}

Sumber : Data diolah, 2018

Data Top Brand Award pada Tahun 2017 untuk kategori produk olahraga dapat dilihat bahwa ada 9 merek yang tergolong empat kategori produk olahraga terbaik yang di ungguli oleh merek Adidas, Nike, Puma, Converse, Diadora, Eagle, Reebok, Yonex, dan Speedo. Data tersebut menyebutkan bahwa produk olahraga kategori tas olahraga dengan presentase tertinggi diraih oleh merek Adidas dengan presentase sebesar 45.7 persen, kemudian untuk pakaian renang diraih oleh merek Diadora dengan presentase sebesar 27.8 persen, pakaian olahraga dengan presentase tertinggi sebesar 54.3 persen diraih oleh Adidas dan untuk kategori sepatu olahraga juga diraih oleh Adidas dengan presentase sebesar 38.2 persen. Dengan demikian Adidas menjadi satu-satunya merek yang mengungguli tiga jenis produk sekaligus dalam satu kategori karena meraih presentase dengan jumlah tertinggi dalam produk tas olahraga, pakaian olahraga dan sepatu olahraga. Semua merek produk olahraga tersebut merupakan merek yang mampu bersaing di pasaran saat ini. Salah satu perusahaan produsen produk olahraga terkenal yang mampu bersaing dalam kategori produk olahraga di Denpasar adalah perusahaan asal Jerman yaitu Adidas.

Adidas mampu berdiri sebagai salah satu merek yang kuat di mata masyarakat dan mampu memenuhi kebutuhan akan peralatan olahraga, terbukti dengan meraih Top Brand Awards 2017 untuk tiga kategori peralatan olahraga terbaik. Perusahaan terkenal berbasis olahraga lainnya adalah Nike. Perusahaan produk olahraga dari Amerika Serikat yang terkenal dengan logonya ini mampu menguasai pasar di berbagai wilayah Indonesia. Terlebih lagi Nike pernah mendirikan pabrik mereka di Indonesia, yang berlokasi di Tangerang dan Serang, yang menyebabkan informasi dan pengetahuan masyarakat Indonesia semakin tinggi terhadap merek Nike.

Dengan mengetahui informasi mengenai aset merek yang mempengaruhi penciptaan brand equity, maka perusahaan akan dapat mempertahankan kesuksesan merek yang telah diciptakannya (Maulidina \& Ariyanti, 2016). Nike dan Adidas merupakan merek produk olahraga terkenal yang memperhatikan setiap elemen dari brand equity sebagai dasar perkembangan produknya saat ini hingga dikenal oleh konsumen. Terbukti kedua merek ini mampu berada dipuncak kategori produk olahraga. Namun tentu saja terdapat perbedaan keunggulan dari 
setiap elemen brand equity yang ada baik dari Nike maupun Adidas. Pesaing mungkin akan menawarkan produk yang serupa, namun pesaing tidak akan mampu menawarkan janji emosional yang sama

Hal ini karena Nike dan Adidas yang merupakan rival sehingga antar pesaing tidak mungkin menawarkan kekuatan elemen yang sama kepada konsumen di setiap aspek, maka dari itu akan selalu ada perbedaan yang lebih baik dari masing-masing elemen tersebut. Masing-masing produk memiliki ciri khas nya sendiri, apabila suatu produk telah memiliki ciri khas tersendiri maka akan mempermudah persaingan dan membuat konsumen secara cepat menyukai produk tersebut

Untuk mampu mengungguli pesaing, maka diperlukan brand equity yang kuat. Brand equity sebagai nilai tambah yang diberikan pada produk dan jasa. Brand equity berkaitan dengan konsumen menempatkan keyakinan yang lebih besar pada sebuah merek dibandingkan merek pesaingnya sekaligus menambah loyalitas konsumen dan kesediaan membayar lebih untuk merek tersebut (Sasmita \& Suki, 2015).

Brand equity dapat dikatakan aktiva tak terwujud yang memiliki peranan penting dan dapat memberikan keunggulan kompetitif bagi perusahaan (Shahin et al., 2012) Brand equity mampu berperan sebagai identitas merek seperti logo, simbol, merek dagang, dan slogan untuk dapat mengidentifikasi dan melihat bagaimana pengaruh produk terhadap konsumen. Brand equity yang tinggi akan memberikan nilai tambah yang diperoleh konsumen dari produk tersebut akan semakin tinggi dari merek-merek pesaing.

Omer (2014) menyatakan bahwa brand equity juga mampu memberikan beberapa keunggulan seperti peluang dan kekuatan komunikasi. Dengan demikian, perusahaan yang ingin tetap bertahan dan memenangkan persaingan sangat perlu mengetahui kondisi brand equity produknya melalui riset terhadap elemen brand equity (Nor et al., 2016).

Berdasarkan latar belakang yang telah dipaparkan, maka yang menjadi pokok masalah dalam penelitian ini adalah apakah brand equity produk olahraga Nike berbeda dengan merek Adidas. Tujuan yang hendak dicapai dalam penelitian ini adalah untuk mengetahui perbedaan brand equity produk olahraga merek Nike dengan merek Adidas (studi pada atlet Kota Denpasar).

Beberapa rumusan masalah yang dikaji berdasarkan latar belakang di atas adalah sebagai berikut : 1) Adakah perbedaan signifikan kesadaran merek produk olahraga merek Nike dengan merek Adidas ? 2) Adakah perbedaan signifikan asosiasi merek produk olahraga merek Nike dengan merek Adidas ? 3) Adakah perbedaan signifikan persepsi kualitas produk olahraga merek Nike dengan merek Adidas ? 4) Adakah perbedaan signifikan posisi loyalitas merek produk olahraga merek Nike dengan merek Adidas?

Hasil dari penelitian ini diharapkan dapat memberikan bahan yang bermanfaat bagi pengembangan ilmu penelitian dalam bidang manajemen pemasaran kaitannya dengan analisis perbandingan brand equity dari dua merek berbeda. Untuk mengetahui keunggulan dan kelemahan brand equity dari produk perusahaan, dan membedakan dari pesaingnya. Hal ini sebagai sumbangan 
pemikiran dan bahan pertimbangan perusahaan untuk meningkatkan strategi perusahaan terutama dalam brand equity pada produk.

Kesadaran merek adalah kesanggupan untuk mengenali atau mengingat kembali tentang kesadaran produk. Penelitian yang dilakukan oleh Putra dan Aksari (2018) yang menunjukkan terdapat perbedaan kesadaran merek dalam brand equity produk kopi bubuk merek Indocafe dan Good Day di Kota Denpasar. Hasil penelitian ini sesuai dengan hasil penelitian sebelumnya yang dilakukan oleh Darmawan \& Syarifah (2016) serta Maulidina \& Ariyanti (2016) yang menunjukkan terdapat perbedaan kesadaran merek antara merek produk yang mereka teliti. Berdasarkan proposisi di atas, maka dapat dirumuskan hipotesis sebagai berikut :

$\mathrm{H}_{1}$ : Terdapat perbedaan signifikan kesadaran merek antara produk olahraga merek Nike dengan merek Adidas.

Asosiasi merek adalah keseluruhan kesan yang ada di benak konsumen yang berkenaan dengan ingatannya. Penelitian yang dilakukan Pramana \& Aksari (2018) menyebutkan bahwa terdapat perbedaan asosiasi merek pada perbandingan brand equity produk kopi bubuk merek Indocafe dengan merek Good Day di Kota Denpasar. Pernyataan lain diperkuat oleh penelitian yang dilakukan oleh Darmawan \& Syarifah (2016), serta Maulidina \& Ariyanti (2016). Berdasarkan proporsi di atas, maka dapat dirumuskan hipotesis sebagai berikut :

$\mathrm{H}_{2}$ : Terdapat perbedaan signifikan asosiasi merek antara produk olahraga merek

Nike dengan merek Adidas.

Persepsi kualitas merek adalah persepsi konsumen terhadap keseluruhan atau keunggulan. Penelitian yang dilakukan oleh Nainggolan (2018) menunjukkan bahwa persepsi kualitas kartu XL lebih tinggi dibandingkan SimPATI. Ini berarti konsumen kartu XL lebih puas dari segi kualitas dibandingkan kartu SimPATI. Pernyataan lain diperkuat oleh penelitian yang dilakukan oleh Shamma \& Hasan (2011), Tong \& Hawley (2009), Darmawan \& Syarifah (2016), serta Tan et al., (2012). Berdasarkan proporsi di atas, maka dapatkan dirumuskan hipotesis sebagai berikut:

$\mathrm{H}_{3}$ : Terdapat perbedaan signifikan persepsi kualitas merek antara produk olahraga merek Nike dengan merek Adidas.

Loyalitas merek adalah ukuran kesetiaan konsumen. Penelitian dari Nainggolan (2018) menyatakan bahwa terdapat perbedaan loyalitas merek antara kartu XL dan SimPATI. Pernyataan ini juga diperkuat dengan penelitian yang dilakukan oleh Fayrene \& Lee (2011), Darmawan \& Syarifah (2016), Maulidina \& Ariyanti (2016). Berdasarkan proporsi di atas, maka dapat dirumuskan hipotesis sebagai berikut :

$\mathrm{H}_{4}$ : Terdapat perbedaan signifikan loyalitas merek merek antara produk olahraga merek Nike dan produk olahraga merek Adidas.

\section{METODE PENELITIAN}

Penelitian ini dilakukan di Kota Denpasar dengan subjek penelitian yaitu atlet Kota Denpasar yang menggunakan produk olahraga merek Nike dengan merek Adidas. Jenis penelitian ini adalah komparatif. Jenis data dalam penelitian ini adalah data kuantitatif berupa hasil survei yang sudah dibuat dalam bentuk 
data dan data kualitatif berupa sejarah perusahaan dan kesimpulan dari pendapat responden mengenai analisis perbandingan produk olahraga merek Nike dengan merek Adidas pada atlet Kota Denpasar.

Sumber data yang digunakan dalam penelitian ini adalah data primer dan data sekunder. Variabel yang diteliti dalam penelitian ini adalah kesadaran merek (brand awareness), asosiasi merek (brand association), persepsi kualitas (perceived quality), dan loyalitas merek (brand loyalty) produk olahraga merek Nike dengan merek Adidas.

Sampel yang diambil dalam penelitian ini berjumlah 100 orang responden. Penentuan jumlah responden tersebut berdasarkan pernyataan Roscoe (1982) dalam Sugiyono (2016) yang menyatakan bila ukuran sampel yang layak dalam penelitian yaitu antara 30 sampai 500. Penelitian ini menggunakan teknik pengambilan sampel Purposive Sampling. Purposive Sampling merupakan penentuan sampel dengan pertimbangan tertentu.

Adapun pertimbangan dalam penelitian ini adalah : 1) Berusia minimal 15 tahun hingga maksimal 35 tahun. 2) Berdomisili di Kota Denpasar dan merupakan atlet Kota Denpasar. 3) Atlet dari cabang olahraga yang dipertandingkan di PORPROV/PON. 4) Sudah pernah membeli produk olahraga merek Nike dan merek Adidas kategori apapun misalnya tas olahraga, pakaian renang, pakaian olahraga, dan sepatu olahraga minimal dua kali proses pembelian untuk kedua merek. 5) Proses pembelian dilakukan dalam periode setahun terakhir. 6) Tidak terlibat hubungan promosi maupun kerjasama dengan merek Nike maupun merek Adidas.

Kriteria pengukuran skala likert dalam penelitian ini adalah sebagai berikut : 1) Skor lima untuk jawaban sangat setuju dengan kode SS; 2) Skor empat untuk jawaban setuju dengan kode $S$; 3 ) Skor tiga untuk jawaban cukup setuju dengan kode CS; 4) Skor dua untuk jawaban tidak setuju dengan kode TS; 4) Skor lima untuk jawaban sangat tidak setuju dengan kode STS.

Variabel yang digunakan dalam penelitian ini adalah brand equity dengan sub variabel sebagai berikut : kesadaran merek, asosiasi merek, persepsi kualitas dan loyalitas merek. Variabel brand equity pada penelitian ini didefinisikan sebagai nilai dari produk olahraga merek Nike dan merek Adidas.

Pembuktian hipotesis komparatif dilakukan dengan menggunakan uji beda t-test dengan menggunakan alat bantu SPSS for Windows. Pinar et al.,(2012) menyatakan bahwa pengambilan keputusan yang dijadikan acuan adalah jika probabilitas atau signifikansinya $\leq 0,05$ maka hipotesis yang menyatakan terdapat perbedaan brand equity produk olahraga merek Nike dengan merek Adidas dapat diterima begitu pula sebaliknya, jika probabilitas atau signifikansinya $\geq 0,05$ maka hipotesis yang menyatakan terdapat perbedaan brand equity dapat ditolak.

\section{HASIL DAN PEMBAHASAN}

Jumlah responden dalam penelitian ini adalah 100 orang. Responden yang memberikan tanggapan dalam penelitian ini sudah memenuhi kriteria yang telah ditentukan yaitu merupakan atlet Kota Denpasar. Berdasarkan jenis kelamin, responden atlet terbanyak adalah laki-laki dengan jumlah 64 persen, sedangkan perempuan sebanyak 36 persen. Kemudian pengelompokkan 
berdasarkan usia, jumlah tertinggi yaitu pada atlet usia 21-25 tahun sebanyak 48 persen, diikuti oleh atlet usia 15-20 tahun sebanyak 22 persen, kemudian atlet usia 26-30 tahun sebanyak 17 orang dan jumlah terendah adalah atlet usia 31-35 tahun sebanyak 13 persen. Dari 100 persen responden dalam penelitian ini menunjukkan bahwa produk olahraga bermerek paling banyak dikonsumsi oleh atlet yang tergolong usia produktif yaitu usia 21-25 tahun, sedangkan atlet usia diantara 31-35 tahun paling sedikit mengkonsumsi produk olahraga bermerek.

Pengelompokkan berdasarkan cabang olahraga, jumlah tertinggi berada pada atlet cabang olahraga atletik yaitu sebanyak 16 persen, diikuti oleh cabang olahraga kempo sebanyak 12 persen, dan cabang olahraga basket sebanyak 10 persen. Sementara cabang olahraga lain seperti judo, dansa, dan cricket masingmasing sebanyak 7 persen. Kemudian cabang olahraga panahan dan voli masingmasing sebanyak 6 persen. Lalu cabang olahraga seperti karate, tarung derajat, dan panjang tebing masing-masing sebanyak 4 persen. Dan cabang olahraga tinju dan softball masing-masing sebanyak 3 persen. Hal ini menunjukkan bahwa dalam penelitian ini atlet cabang olahraga atletik yang paling sering mengkonsumsi produk olahraga bermerek.

Pengelompokkan berdasarkan pendapatan atlet, jumlah terbanyak pada atlet dengan penghasilan Rp 1.000.000 - Rp 5.000.000 yaitu sebesar 45 persen, kemudian atlet dengan penghasilan Rp 5.000.000 - Rp 10.000.000 berada pada posisi kedua sebesar 30 persen, lalu atlet dengan penghasilan kurang dari Rp 1.000 .000 berada di posisi ketiga dengan persentase sebesar 20 persen dan posisi terakhir adalah atlet dengan penghasilan di atas Rp 10.000.000 sebesar 5 persen.

Tabel 3.

Faktor Yang Dipertimbangkan Atlet Memilih Produk Olahraga

\begin{tabular}{lcccc}
\hline \multirow{2}{*}{ Faktor } & \multicolumn{2}{c}{ Jawaban } & \multicolumn{2}{c}{ Total Responden } \\
\cline { 2 - 5 } & $\begin{array}{r}\text { Jumlah } \\
\text { (orang) }\end{array}$ & $\begin{array}{c}\text { Persentase } \\
(\%)\end{array}$ & $\begin{array}{c}\text { Jumlah } \\
\text { (orang) }\end{array}$ & $\begin{array}{c}\text { Persentase } \\
(\%)\end{array}$ \\
\hline 1. Harga & 34 & 34 & 100 & 100 \\
2. Merek & 22 & 22 & 100 & 100 \\
3. Kualitas & 60 & 60 & 100 & 100 \\
4. Model & 11 & 11 & 100 & 100 \\
5. Iklan & 3 & 3 & 100 & 100 \\
6. Manfaat & 7 & 10 & 100 & 100 \\
7.Ketersediaan & 5 & 18 & 100 & 100 \\
$\quad$ barang & & 7 & 100 & 100 \\
8. Bahan & 10 & 13 & 100 & \\
9.Tingkat & 13 & & &
\end{tabular}

Tabel 3. menunjukkan bahwa faktor kualitas adalah faktor yang paling dipertimbangkan oleh responden dalam penelitian ini ketika membeli produk tersebut, yaitu sebanyak 60 persen dari 100 persen responden. Faktor kedua yang dipertimbangkan oleh responden adalah harga sebanyak 34 persen responden. Faktor ketiga adalah merek sebanyak 22 persen responden. Faktor berikutnya adalah tingkat kenyamanan sebanyak 13 persen responden. Kemudian faktor 
model sebanyak 11 persen responden, dan faktor bahan sebanyak 10 persen responden lalu diikuti oleh faktor manfaat sebanyak 7 persen.

Faktor iklan dan ketersediaan barang bukan merupakan faktor yang terlalu penting bagi atlet Kota Denpasar dalam membeli produk olahraga, karena berdasarkan tabel dalam penelitian ini dapat dilihat bahwa faktor iklan hanya sebanyak 3 persen dan ketersediaan barang hanya sebanyak 5 persen.

Tabel 4.

Hasil Uji Validitas

\begin{tabular}{|c|c|c|c|c|c|}
\hline No. & $\begin{array}{l}\text { Variabel } \\
\text { Penelitian }\end{array}$ & $\begin{array}{l}\text { Nilai } r \text { hitung } \\
\text { NIKE }\end{array}$ & $\begin{array}{l}\text { Nilai } r \text { hitung } \\
\text { ADIDAS }\end{array}$ & Nilai $r$ tabel & Keterangan \\
\hline \multicolumn{6}{|c|}{ KESADARAN MEREK (BRAND AWARENESS) } \\
\hline \multirow{3}{*}{1} & KM1 & 0.763 & 0.918 & 0.196 & Valid \\
\hline & KM2 & 0.769 & 0.864 & 0.196 & Valid \\
\hline & KM3 & 0.745 & 0.868 & 0.196 & Valid \\
\hline \multicolumn{6}{|c|}{ ASOSIASI MEREK (BRAND ASSOCIATION) } \\
\hline \multirow{4}{*}{2} & AM1 & 0.855 & 0.845 & 0.196 & Valid \\
\hline & AM2 & 0.838 & 0.774 & 0.196 & Valid \\
\hline & AM3 & 0.828 & 0.820 & 0.196 & Valid \\
\hline & AM4 & 0.869 & 0.770 & 0.196 & Valid \\
\hline \multicolumn{6}{|c|}{ PERSEPSI KUALITAS (PERCEIVED QUALITY) } \\
\hline \multirow{3}{*}{3} & PK1 & 0.778 & 0.666 & 0.196 & Valid \\
\hline & PK2 & 0.842 & 0.732 & 0.196 & Valid \\
\hline & PK3 & 0.844 & 0.701 & 0.196 & Valid \\
\hline \multicolumn{6}{|c|}{ LOYALITAS MEREK (BRAND LOYALTY) } \\
\hline \multirow{3}{*}{4} & L1 & 0.794 & 0.733 & 0.196 & Valid \\
\hline & L2 & 0.835 & 0.767 & 0.196 & Valid \\
\hline & L3 & 0.848 & 0.746 & 0.196 & Valid \\
\hline
\end{tabular}

Sumber : Data primer diolah, 2018

Uji validitas pada Tabel 4. menunjukkan bahwa nilai $\mathrm{r}$ hitung produk olahraga merek Nike dengan merek Adidas menggunakan 30 sampel lebih besar dari nilai $\mathrm{r}$ Tabel maka variabel penelitian kesadaran merek, asosiasi merek, persepsi kualitas, serta loyalitas merek dapat dinyatakan valid.

Uji reliabilitas digunakan Alpha Cronbach. Berdasarkan hasil perhitungan yang diperoleh Alpha Cronbach $\geq 0,6$. Hal ini menunjukkan bahwa pengukuran tersebut dapat menghasilkan hasil yang konsisten, apabila dilakukan pengukuran kembali terhadap objek yang sama, dengan data yang sama.

Uji reliabilitas pada Tabel 5. menunjukkan nilai Cronbach's Alpha yang dihasilkan masing-masing variabel yang digunakan lebih besar sama dengan dari 0.6 sehingga dapat disimpulkan bahwa kuesioner yang digunakan sudah reliabel. Karena kuesioner sudah dinyatakan valid dan reliabel, maka kuesioner dapat digunakan sebagai alat ukur dan analisa lebih lanjut. 
Tabel 5.

Hasil Uji Reliabilitas

\begin{tabular}{ccccc}
\hline No. & Variabel Penelitian & $\begin{array}{c}\text { Cronbach's } \\
\text { Apha NIKE }\end{array}$ & $\begin{array}{c}\text { Cronbach's } \\
\text { Apha ADIDAS }\end{array}$ & Keterangan \\
\hline 1 & Kesadaran merek & 0.728 & 0.885 & Reliabel \\
2 & Asosiasi Merek & 0.877 & 0.814 & Reliabel \\
3 & Persepsi Kualitas & 0.802 & 0.751 & Reliabel \\
4 & Loyalitas Merek & 0.743 & 0.881 & Reliabel \\
\hline
\end{tabular}

Sumber : Data primer diolah, 2018

Tabel 6.

Deskriptif Kesadaran Merek Nike

\begin{tabular}{|c|c|c|c|c|c|c|c|c|c|}
\hline \multirow[t]{2}{*}{ No. } & \multirow[t]{2}{*}{ Indikator } & \multicolumn{5}{|c|}{ Jawaban Responden } & \multirow{2}{*}{$\begin{array}{c}\text { Jumlah } \\
\text { Skor }\end{array}$} & \multirow{2}{*}{$\begin{array}{l}\text { Rata- } \\
\text { Rata }\end{array}$} & \multirow[t]{2}{*}{ Ket. } \\
\hline & & 1 & 2 & 3 & 4 & 5 & & & \\
\hline 1. & $\begin{array}{l}\text { Produk olahraga merek Nike } \\
\text { adalah merek yang pertama } \\
\text { kali muncul dalam benak saya }\end{array}$ & 0 & 1 & 14 & 47 & 38 & 422 & 4,22 & \\
\hline
\end{tabular}

2. Produk olahraga merek Nike adalah merek yang pertama $\begin{array}{lllllllll}\begin{array}{l}\text { kali terpikirkan ketika hendak } \\ \text { membeli sebuah produk }\end{array} & 1 & 2 & 3 & 40 & 54 & 444 & 4,44 & \begin{array}{l}\text { Sangat } \\ \text { Setuju }\end{array}\end{array}$ olahraga

3. Produk olahraga merek Nike dengan mudah saya kenali ketika melihat logo, kemasan, $\quad \begin{array}{llllllll}0 & 3 & 13 & 53 & 31 & 412 & 4,12 & \text { Setuju }\end{array}$ dan iklan.

Rata-rata keseluruhan variabel kesadaran merek Nike

Sumber : Data primer diolah, 2018

Hasil perhitungan Tabel 6. menunjukkan hasil deskripsi jawaban responden mengenai penilaian terhadap variabel kesadaran merek yang diukur menggunakan tiga indikator dapat dijelaskan yaitu Pernyataan "Produk olahraga merek Nike adalah merek yang pertama kali muncul dalam benak saya" memperoleh nilai rata-rata sebesar 4,22, maka dapat diambil kesimpulan bahwa atlet Kota Denpasar menyatakan sangat setuju jika produk olahraga merek Nike yang muncul di benak mereka pertama kali.

Pernyataan "Produk olahraga merek Nike adalah merek yang pertama kali terpikirkan ketika hendak membeli sebuah produk olahraga" memperoleh nilai rata-rata sebesar 4,44, maka dapat diambil kesimpulan bahwa atlet Kota Denpasar menyatakan sangat setuju jika produk olahraga merek Nike yang muncul pertama kali ketika hendak membeli produk olahraga.

Pernyataan "Produk olahraga merek Nike dengan mudah saya kenali ketika melihat logo, kemasan, dan iklannya di televisi" memperoleh nilai rata-rata sebesar 4,12, maka dapat diambil kesimpulan bahwa atlet Kota Denpasar 
menyatakan setuju bahwa produk olahraga merek Nike mudah dikenali melalui iklan, logo, dan kemasan. Secara keseluruhan nilai rata-rata total jawaban responden mengenai variabel kesadaran merek Nike sebesar 4,26 yaitu termasuk kriteria sangat setuju.

Tabel 7.

Deskripsi Kesadaran Merek Adidas

\begin{tabular}{|c|c|c|c|c|c|c|c|c|c|}
\hline \multirow[t]{2}{*}{ No. } & \multirow[t]{2}{*}{ Indikator } & \multicolumn{5}{|c|}{ Jawaban Responden } & \multirow{2}{*}{$\begin{array}{c}\text { Jumlah } \\
\text { Skor }\end{array}$} & \multirow{2}{*}{$\begin{array}{l}\text { Rata- } \\
\text { Rata }\end{array}$} & \multirow[t]{2}{*}{ Ket. } \\
\hline & & 1 & 2 & 3 & 4 & 5 & & & \\
\hline 1. & $\begin{array}{l}\text { Produk olahraga merek Adidas } \\
\text { adalah merek yang pertama } \\
\text { kali muncul dalam benak saya }\end{array}$ & 1 & 1 & 2 & 44 & 52 & 445 & 4,45 & $\begin{array}{l}\text { Sangat } \\
\text { setuju }\end{array}$ \\
\hline 2. & $\begin{array}{l}\text { Produk olahraga merek Adidas } \\
\text { adalah merek yang pertama } \\
\text { kali terpikirkan ketika hendak } \\
\text { membeli sebuah produk } \\
\text { olahraga }\end{array}$ & 0 & 1 & 5 & 42 & 52 & 445 & 4,45 & $\begin{array}{l}\text { Sangat } \\
\text { setuju }\end{array}$ \\
\hline 3. & $\begin{array}{l}\text { Produk olahraga merek Adidas } \\
\text { dengan mudah saya kenali } \\
\text { ketika melihat logo, kemasan, } \\
\text { dan iklannya di televise }\end{array}$ & 1 & 2 & 0 & 54 & 43 & 436 & 4,36 & $\begin{array}{l}\text { Sangat } \\
\text { setuju }\end{array}$ \\
\hline & Rata-rata keseluruhan var & abe & sa & al & rek & didas & & 4,42 & $\begin{array}{l}\text { Sangat } \\
\text { setuju }\end{array}$ \\
\hline
\end{tabular}

Sumber : Data primer diolah, 2018

Hasil perhitungan Tabel 7. menunjukkan hasil deskripsi jawaban responden mengenai penilaian terhadap variabel kesadaran merek yang diukur menggunakan tiga indikator dapat dijelaskan sebagai berikut : Pernyataan "Produk olahraga merek Adidas adalah merek yang pertama kali muncul dalam benak saya" memperoleh nilai rata-rata sebesar 4,45, maka dapat diambil kesimpulan bahwa atlet Kota Denpasar menyatakan sangat setuju bahwa produk olahraga merek Adidas yang muncul pertama kali dalam benak mereka.

Pernyataan "Produk olahraga merek Adidas adalah merek yang pertama kali terpikirkan ketika hendak membeli sebuah produk olahraga" memperoleh nilai rata-rata sebesar 4,45, maka dapat diambil kesimpulan bahwa atlet Kota Denpasar menyatakan sangat setuju jika produk olahraga merek Adidas adalah merek yang pertama kali terpikirkan ketika hendak membeli sebuah produk olahraga.

Pernyataan "Produk olahraga merek Adidas dengan mudah saya kenali ketika melihat logo, kemasan, dan iklannya di televisi" memperoleh nilai ratarata sebesar 4,36, maka dapat diambil kesimpulan jika atlet Kota Denpasar menyatakan sangat setuju bahwa produk olahraga merek Adidas mudah dikenali melalui logo, kemasan dan iklan.

Secara keseluruhan nilai rata-rata total jawaban responden mengenai variabel kesadaran merek Adidas sebesar 4,42 yaitu termasuk kriteria sangat setuju. Secara rinci hasil penelitian mengenai deskripsi jawaban responden tentang penilaian terhadap asosiasi merek produk olahraga merek Nike dan merek Adidas dapat dilihat pada Tabel 8. dan Tabel 9. 
Tabel 8.

Deskripsi Asosiasi Merek Nike

\begin{tabular}{|c|c|c|c|c|c|c|c|c|c|}
\hline \multirow[t]{2}{*}{ No. } & \multirow[t]{2}{*}{ Indikator } & \multicolumn{5}{|c|}{ Jawaban Responden } & \multirow{2}{*}{$\begin{array}{c}\text { Jumlah } \\
\text { Skor } \\
\end{array}$} & \multirow{2}{*}{$\begin{array}{l}\text { Rata- } \\
\text { Rata }\end{array}$} & \multirow[t]{2}{*}{ Ket. } \\
\hline & & 1 & 2 & 3 & 4 & 5 & & & \\
\hline 1. & $\begin{array}{l}\text { Produk olahraga merek Nike } \\
\text { memiliki desain yang unik dan } \\
\text { menarik }\end{array}$ & 1 & 2 & 8 & 53 & 36 & 421 & 4,21 & $\begin{array}{l}\text { Sangat } \\
\text { setuju }\end{array}$ \\
\hline 2. & $\begin{array}{l}\text { Produk olahraga merek Nike } \\
\text { diproduksi oleh perusahaan } \\
\text { dengan reputasi yang baik }\end{array}$ & 1 & 2 & 3 & 54 & 39 & 425 & 4,25 & $\begin{array}{l}\text { Sangat } \\
\text { setuju }\end{array}$ \\
\hline 3. & $\begin{array}{l}\text { Produk olahraga merek Nike } \\
\text { dapat dengan mudah ditemui di } \\
\text { pusat perbelanjaan dan mall } \\
\text { besar }\end{array}$ & 0 & 4 & 24 & 45 & 27 & 395 & 3,95 & Setuju \\
\hline 4. & $\begin{array}{l}\text { Produk olahraga merek Nike } \\
\text { membantu kegiatan latihan } \\
\text { saya dengan baik }\end{array}$ & 1 & 1 & 19 & 51 & 28 & 404 & 4,04 & Setuju \\
\hline & Rata-rata keseluruhan & ria & & asi i & rek & & & 4,11 & Setuju \\
\hline
\end{tabular}

Hasil perhitungan Tabel 8. menunjukkan hasil deskripsi jawaban responden mengenai penilaian terhadap variabel asosiasi merek yang diukur menggunakan empat indikator dapat dijelaskan sebagai berikut : Pernyataan "Produk olahraga merek Nike memiliki desain yang unik dan menarik" memperoleh nilai rata-rata sebesar 4,21, maka dapat diambil kesimpulan bahwa atlet Kota Denpasar menyatakan sangat setuju jika produk olahraga merek Nike memiliki desain yang unik dan menarik.

Pernyataan "Produk olahraga merek Nike diproduksi oleh perusahaan dengan reputasi yang baik" memperoleh nilai rata-rata sebesar 4,25, maka dapat diambil kesimpulan bahwa atlet Kota Denpasar menyatakan sangat setuju jika Nike diproduksi oleh perusahaan dengan reputasi baik.

Pernyataan "Produk olahraga merek Nike dapat dengan mudah ditemui di pusat perbelanjaan dan mall besar" memperoleh nilai rata-rata sebesar 3,95, maka dapat diambil kesimpulan bahwa atlet Kota Denpasar menyatakan setuju jika produk olahraga merek Nike dapat dengan mudah ditemui di pusat perbelanjaan.

Pernyataan "Produk olahraga merek Nike membantu kegiatan latihan saya dengan baik" memperoleh nilai rata-rata sebesar 4,04, maka dapat diambil kesimpulan bahwa atlet Kota Denpasar menyatakan setuju jika produk olahraga merek Nike membantu kegiatan latihan mereka.

Secara keseluruhan nilai rata-rata total jawaban responden mengenai variabel asosiasi merek Nike sebesar 4,11 yaitu termasuk kriteria setuju.

Hasil perhitungan Tabel 9. menunjukkan hasil deskripsi jawaban responden mengenai penilaian terhadap variabel asosiasi merek yang diukur menggunakan empat indikator dapat dijelaskan sebagai berikut : Pernyataan "Produk olahraga merek Adidas memiliki desain yang unik dan menarik" memperoleh nilai rata-rata sebesar 4,36, maka dapat diambil kesimpulan bahwa atlet Kota Denpasar 
menyatakan sangat setuju jika produk olahraga merek Adidas memiliki desain yang unik dan menarik.

Tabel 9.

Deskripsi Asosiasi Merek Adidas

\begin{tabular}{|c|c|c|c|c|c|c|c|c|c|}
\hline \multirow[t]{2}{*}{ No. } & \multirow[t]{2}{*}{ Indikator } & \multicolumn{5}{|c|}{ Jawaban Responden } & \multirow{2}{*}{$\begin{array}{c}\text { Jumlah } \\
\text { Skor }\end{array}$} & \multirow{2}{*}{$\begin{array}{l}\text { Rata- } \\
\text { Rata }\end{array}$} & \multirow[t]{2}{*}{ Ket. } \\
\hline & & 1 & 2 & 3 & 4 & 5 & & & \\
\hline 1. & $\begin{array}{l}\text { Produk olahraga merek Adidas } \\
\text { memiliki desain yang unik dan } \\
\text { menarik }\end{array}$ & 1 & 2 & 0 & 54 & 43 & 436 & 4,36 & $\begin{array}{l}\text { Sangat } \\
\text { Setuju }\end{array}$ \\
\hline 2. & $\begin{array}{l}\text { Produk olahraga merek Adidas } \\
\text { diproduksi oleh perusahaan } \\
\text { dengan reputasi yang baik }\end{array}$ & 0 & 1 & 14 & 40 & 45 & 475 & 4,75 & $\begin{array}{l}\text { Sangat } \\
\text { Setuju }\end{array}$ \\
\hline 3. & $\begin{array}{l}\text { Produk olahraga merek Adidas } \\
\text { dapat dengan mudah ditemui di } \\
\text { pusat perbelanjaan dan mall } \\
\text { besar }\end{array}$ & 1 & 2 & 3 & 30 & 64 & 454 & 4,54 & $\begin{array}{l}\text { Sangat } \\
\text { Setuju }\end{array}$ \\
\hline 4. & $\begin{array}{l}\text { Produk olahraga merek Adidas } \\
\text { membantu kegiatan latihan } \\
\text { saya dengan baik }\end{array}$ & 0 & 3 & 13 & 53 & 31 & 412 & 4,12 & Setuju \\
\hline & Rata-rata keseluruh & val & deI & DSla & 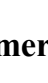 & & & 4,44 & $\begin{array}{l}\text { Sangat } \\
\text { Setuju }\end{array}$ \\
\hline
\end{tabular}

Sumber : Data primer diolah, 2018

Pernyataan "Produk olahraga merek Adidas diproduksi oleh perusahaan dengan reputasi yang baik" memperoleh nilai rata-rata sebesar 4,75, maka dapat diambil kesimpulan bahwa atlet Kota Denpasar sangat setuju jika Nike diproduksi oleh perusahaan dengan reputasi baik.

Pernyataan "Produk olahraga merek Adidas dapat dengan mudah ditemui di pusat perbelanjaan dan mall besar" memperoleh nilai rata-rata sebesar 4,54, maka dapat diambil kesimpulan bahwa atlet Kota Denpasar menyatakan sangat setuju jika produk olahraga merek Nike dapat dengan mudah ditemui di pusat perbelanjaan.

Pernyataan "Produk olahraga merek Adidas membantu kegiatan latihan saya dengan baik" memperoleh nilai rata-rata sebesar 4,12, maka dapat diambil kesimpulan bahwa atlet Kota Denpasar menyatakan setuju jika produk olahraga merek Nike membantu kegiatan latihan mereka.

Secara keseluruhan nilai rata-rata total jawaban responden mengenai variabel asosiasi merek Adidas sebesar 4,44 yaitu termasuk kriteria sangat setuju. Secara rinci hasil penelitian mengenai deskripsi jawaban responden tentang penilaian terhadap persepsi kualitas produk olahraga merek Nike dan merek Adidas dapat dilihat pada Tabel 10. dan Tabel 11.

Hasil perhitungan Tabel 10. menunjukkan hasil deskripsi jawaban responden mengenai penilaian terhadap variabel persepsi kualitas yang diukur menggunakan tiga indikator dapat dijelaskan sebagai berikut: Pernyataan "Produk olahraga merek Nike memiliki kualitas yang baik" memperoleh nilai rata-rata 
sebesar 4,14, maka dapat diambil kesimpulan bahwa atlet Kota Denpasar menyatakan setuju jika produk olahraga merek Nike memiliki kualitas yang baik.

Tabel 10.

Deskripsi Persepsi Kualitas Nike

\begin{tabular}{|c|c|c|c|c|c|c|c|c|c|}
\hline \multirow[t]{2}{*}{ No. } & \multirow[t]{2}{*}{ Indikator } & \multicolumn{5}{|c|}{ Jawaban Responden } & \multirow{2}{*}{$\begin{array}{l}\text { Jumlah } \\
\text { Skor }\end{array}$} & \multirow{2}{*}{$\begin{array}{l}\text { Rata- } \\
\text { Rata }\end{array}$} & \multirow[t]{2}{*}{ Ket. } \\
\hline & & 1 & 2 & 3 & 4 & 5 & & & \\
\hline 1. & $\begin{array}{l}\text { Produk olahraga merek Nike } \\
\text { memiliki kualitas yang baik }\end{array}$ & 0 & 3 & 11 & 55 & 31 & 414 & 4,14 & Setuju \\
\hline 2. & $\begin{array}{l}\text { Harga produk olahraga merek } \\
\text { Nike sesuai dengan kualitas } \\
\text { yang diberikan }\end{array}$ & 1 & 2 & 9 & 59 & 29 & 413 & 4,13 & Setuju \\
\hline 3. & $\begin{array}{l}\text { Produk olahraga merek Nike } \\
\text { memiliki daya tahan dan } \\
\text { tingkat kenyamanan yang baik } \\
\text { ketika digunakan untuk } \\
\text { berlatih }\end{array}$ & 1 & 2 & 4 & 50 & 43 & 432 & 4,32 & $\begin{array}{l}\text { Sangat } \\
\text { setuju }\end{array}$ \\
\hline & Rata-rata keseluruhan & ia & & & lita & ike & & 4,19 & Setuju \\
\hline
\end{tabular}

Pernyataan "Harga produk olahraga merek Nike sesuai dengan kualitas yang diberikan" memperoleh nilai rata-rata sebesar 4,13, maka dapat diambil kesimpulan bahwa atlet Kota Denpasar menyatakan setuju jika produk olahraga merek Nike memiliki harga yang sesuai dengan kualitas yang dihasilkan.

Pernyataan "Produk olahraga merek Nike memiliki daya tahan dan tingkat kenyamanan yang baik ketika digunakan untuk berlatih" memperoleh nilai ratarata sebesar 4,32, maka dapat diambil kesimpulan bahwa atlet Kota Denpasar menyatakan sangat setuju jika produk olahraga merek Nike memiliki daya tahan dan tingkat kenyamanan yang baik digunakan untuk latihan. Secara keseluruhan nilai rata-rata total jawaban responden mengenai variabel persepsi kualitas Nike sebesar 4,19 yaitu termasuk kriteria setuju.

Hasil perhitungan Tabel 10. menunjukkan hasil deskripsi jawaban responden mengenai penilaian terhadap variabel persepsi kualitas yang diukur menggunakan tiga indikator dapat dijelaskan sebagai berikut : Pernyataan "Produk olahraga merek Adidas memiliki kualitas yang baik" memperoleh nilai rata-rata sebesar 4,53, maka dapat diambil kesimpulan bahwa atlet Kota Denpasar menyatakan sangat setuju jika produk olahraga merek Adidas memiliki kualitas yang baik.

Pernyataan "Harga produk olahraga merek Adidas sesuai dengan kualitas yang diberikan" memperoleh nilai rata-rata sebesar 4,48, maka dapat diambil kesimpulan bahwa atlet Kota Denpasar menyatakan sangat setuju jika produk olahraga merek Adidas memiliki harga yang sesuai dengan kualitas yang diberikan.

Pada Tabel 11.menunjukan pernyataan "Produk olahraga merek Adidas memiliki daya tahan dan tingkat kenyamanan yang baik ketika digunakan untuk berlatih" memperoleh nilai rata-rata sebesar 4,48, maka dapat diambil kesimpulan bahwa atlet Kota Denpasar menyatakan sangat setuju jika produk olahraga merek 
Adidas memiliki daya tahan dan tingkat kenyamanan yang baik digunakan untuk latihan.

Secara keseluruhan nilai rata-rata total jawaban responden mengenai variabel persepsi kualitas Adidas sebesar 4,49 yaitu termasuk kriteria sangat setuju.

Tabel 11.

Deskripsi Persepsi Kualitas Adidas

\begin{tabular}{|c|c|c|c|c|c|c|c|c|c|}
\hline \multirow[t]{2}{*}{ No. } & \multirow[t]{2}{*}{ Indikator } & \multicolumn{5}{|c|}{ Jawaban Responden } & \multirow{2}{*}{$\begin{array}{l}\text { Jumlah } \\
\text { Skor }\end{array}$} & \multirow{2}{*}{$\begin{array}{l}\text { Rata- } \\
\text { Rata }\end{array}$} & \multirow[t]{2}{*}{ Ket. } \\
\hline & & 1 & 2 & 3 & 4 & 5 & & & \\
\hline 1. & $\begin{array}{l}\text { Produk olahraga merek Adidas } \\
\text { memiliki kualitas yang baik }\end{array}$ & 0 & 0 & 3 & 41 & 56 & 453 & 4,53 & $\begin{array}{l}\text { Sangat } \\
\text { setuju }\end{array}$ \\
\hline 2. & $\begin{array}{l}\text { Harga produk olahraga merek } \\
\text { Adidas sesuai dengan kualitas } \\
\text { yang diberikan }\end{array}$ & 0 & 0 & 0 & 52 & 48 & 448 & 4,48 & $\begin{array}{l}\text { Sangat } \\
\text { setuju }\end{array}$ \\
\hline 3. & $\begin{array}{l}\text { Produk olahraga merek Adidas } \\
\text { memiliki daya tahan dan } \\
\text { tingkat kenyamanan yang baik } \\
\text { ketika digunakan untuk } \\
\text { berlatih }\end{array}$ & 0 & 0 & 6 & 40 & 54 & 448 & 4,48 & $\begin{array}{l}\text { Sangat } \\
\text { setuju }\end{array}$ \\
\hline & Rata-rata keseluruhan va & abe & er & i kt & itas & lidas & & 4,49 & $\begin{array}{l}\text { Sangat } \\
\text { Setuju }\end{array}$ \\
\hline
\end{tabular}

Tabel 12.

Deskripsi Loyalitas Merek Nike

\begin{tabular}{|c|c|c|c|c|c|c|c|c|c|}
\hline \multirow[t]{2}{*}{ No. } & \multirow[t]{2}{*}{ Indikator } & \multicolumn{5}{|c|}{ Jawaban Responden } & \multirow{2}{*}{$\begin{array}{c}\text { Jumlah } \\
\text { Skor }\end{array}$} & \multirow{2}{*}{$\begin{array}{l}\text { Rata- } \\
\text { Rata }\end{array}$} & \multirow[t]{2}{*}{ Ket. } \\
\hline & & 1 & 2 & 3 & 4 & 5 & & & \\
\hline 1. & $\begin{array}{l}\text { Saya merasa komit dan setia } \\
\text { pada produk olahraga merek } \\
\text { Nike }\end{array}$ & 0 & 3 & 13 & 53 & 31 & 412 & 4,12 & Setuju \\
\hline 2. & $\begin{array}{l}\text { Produk olahraga merek Nike } \\
\text { menjadi pilihan utama saya } \\
\text { untuk di beli }\end{array}$ & 1 & 2 & 10 & 56 & 31 & 414 & 4,14 & Setuju \\
\hline 3. & $\begin{array}{l}\text { Saya akan tetap membeli } \\
\text { produk olahraga merek Nike } \\
\text { selama produk merek } \\
\text { tersebut memuaskan }\end{array}$ & 1 & 2 & 4 & 56 & 37 & 426 & 4,26 & $\begin{array}{l}\text { Sangat } \\
\text { setuju }\end{array}$ \\
\hline & Rata-rata keseluruhan & rial & $10 y$ & $\operatorname{tas} n$ & rek & ike & & 4,17 & $\begin{array}{l}\text { Sangat } \\
\text { setuju }\end{array}$ \\
\hline
\end{tabular}

Hasil perhitungan Tabel 12. menunjukkan hasil deskripsi jawaban responden mengenai penilaian terhadap variabel loyalitas merek yang diukur menggunakan tiga indikator dapat dijelaskan sebagai berikut : Pernyataan "Saya merasa komit dan setia pada produk olahraga merek Nike" memperoleh nilai ratarata sebesar 4,12, maka dapat diambil kesimpulan bahwa atlet Kota Denpasar 
menyatakan setuju jika mereka merasa komit dan setia pada produk olahraga merek Nike.

Pernyataan "Produk olahraga merek Nike menjadi pilihan utama saya untuk di beli" memperoleh nilai rata-rata sebesar 4,14, maka dapat diambil kesimpulan bahwa atlet Kota Denpasar menyatakan setuju jika produk olahraga merek Nike menjadi pilihan utama untuk dibeli.

Pernyataan "Saya akan tetap membeli produk olahraga merek Nike selama produk merek tersebut memuaskan" memperoleh nilai rata-rata sebesar 4,26, maka dapat diambil kesimpulan bahwa atlet Kota Denpasar menyatakan sangat setuju jika produk olahraga merek Nike akan tetap mereka beli selama produk tersebut memuaskan. Secara keseluruhan nilai rata-rata total jawaban responden mengenai variabel loyalitas merek Nike sebesar 4,17 yaitu termasuk kriteria setuju.

\section{Tabel 13.}

Deskripsi Loyalitas Merek Adidas

\begin{tabular}{|c|c|c|c|c|c|c|c|c|c|}
\hline \multirow[t]{2}{*}{ No. } & \multirow[t]{2}{*}{ Indikator } & \multicolumn{5}{|c|}{ Jawaban Responden } & \multirow{2}{*}{$\begin{array}{c}\text { Jumlah } \\
\text { Skor }\end{array}$} & \multirow{2}{*}{$\begin{array}{c}\text { Rata- } \\
\text { Rata } \\
\end{array}$} & \multirow[t]{2}{*}{ Ket. } \\
\hline & & 1 & 2 & 3 & 4 & 5 & & & \\
\hline 1. & $\begin{array}{l}\text { Saya merasa komit dan setia } \\
\text { pada produk olahraga merek } \\
\text { Adidas }\end{array}$ & 0 & 1 & 3 & 36 & 60 & 455 & 4,55 & $\begin{array}{l}\text { Sangat } \\
\text { setuju }\end{array}$ \\
\hline 2. & $\begin{array}{l}\text { Produk olahraga merek Adidas } \\
\text { menjadi pilihan utama saya } \\
\text { untuk di beli }\end{array}$ & 0 & 1 & 0 & 47 & 52 & 450 & 4,50 & $\begin{array}{l}\text { Sangat } \\
\text { setuju }\end{array}$ \\
\hline 3. & $\begin{array}{l}\text { Saya akan tetap membeli } \\
\text { produk olahraga merek Adidas } \\
\text { selama produk merek tersebut } \\
\text { memuaskan }\end{array}$ & 0 & 1 & 8 & 34 & 57 & 447 & 4,47 & $\begin{array}{l}\text { Sangat } \\
\text { setuju }\end{array}$ \\
\hline \multicolumn{8}{|c|}{ Rata-rata keseluruhan variabel loyalitas merek Adidas } & 4,50 & $\begin{array}{c}\text { Sangat } \\
\text { setuju }\end{array}$ \\
\hline
\end{tabular}

Sumber : Data primer diolah, 2018

Tabel 13. menunjukkan hasil deskripsi jawaban responden mengenai penilaian terhadap variabel loyalitas merek yang diukur menggunakan tiga indikator dapat dijelaskan sebagai berikut : Pernyataan "Saya merasa komit dan setia pada produk olahraga merek Adidas" memperoleh nilai rata-rata sebesar 4,55, maka dapat diambil kesimpulan bahwa atlet Kota Denpasar menyatakan setuju jika mereka merasa komit dan setia pada produk olahraga merek Adidas.

Pernyataan "Produk olahraga merek Adidas menjadi pilihan utama saya untuk di beli" memperoleh nilai rata-rata sebesar 4,50, maka dapat diambil kesimpulan bahwa atlet Kota Denpasar menyatakan setuju jika produk olahraga merek Adidas menjadi pilihan utama untuk dibeli.

Pernyataan "Saya akan tetap membeli produk olahraga merek Adidas selama produk merek tersebut memuaskan" memperoleh nilai rata-rata sebesar 4,47, maka dapat diambil kesimpulan bahwa atlet Kota Denpasar menyatakan sangat setuju jika produk olahraga merek Adidas akan tetap mereka beli selama produk tersebut memuaskan. Secara keseluruhan nilai rata-rata total jawaban responden mengenai variabel loyalitas merek Adidas sebesar 4,50 yaitu termasuk kriteria sangat setuju. 
Tabel 14.

Uji Beda T-test Kesadaran Merek

\begin{tabular}{lccc}
\hline \multicolumn{1}{c}{ Sub variabel } & Means & $\begin{array}{c}\text { Paired Differences } \\
\text { Means }\end{array}$ & Sig. (2-tiled) \\
\hline Nike Awareness & 4.26 & -0.15 & 0.002 \\
Adidas Awareness & 4.41 & & \\
\hline Sumber $:$ Data primer diolah, 2018 & &
\end{tabular}

Tabel 14. menunjukkan bahwa rata-rata kesadaran merek produk olahraga merek Nike sebesar 4,26 dan rata-rata kesadaran merek produk olahraga merek Adidas sebesar 4,41. Hal ini berarti rata-rata kesadaran merek produk olahraga merek Nike lebih kecil dibandingkan dengan rata-rata kesadaran merek produk olahraga merek Adidas dengan perbandingan rata-ratanya sebesar 0,15. Probabilitasnya sebesar 0,002 yang berarti kurang dari sama dengan 0,05. Sehingga terdapat perbedaan yang signifikan antara kesadaran merek produk olahraga merek Nike dengan produk olahraga merek Adidas. Responden dalam penelitian ini yaitu atlet Kota Denpasar lebih sadar dengan keberadaan merek Adidas dibandingkan merek Nike terlihat dari rata-rata kesadaran merek Adidas lebih tinggi dibandingkan merek Nike. Atlet Kota Denpasar merasa produk olahraga merek Adidas dianggap memiliki pengenalan merek, logo, maupun iklan yang lebih baik. Atlet Kota Denpasar merasa produk olahraga merek Adidas adalah produk yang mudah diingat dan muncul pertama di benak atlet Kota Denpasar ketika memilih produk olahraga untuk latihan.

Nilai signifikansi pada kesadaran merek adalah 0,002 kurang dari sama dengan 0,05 maka kesimpulannya adalah $\mathrm{H}_{0}$ ditolak dan $\mathrm{H}_{1}$ diterima, ini berarti terdapat perbedaan signifikan produk olahraga merek Nike dengan merek Adidas.

Tabel 15.

Uji Beda T-test Asosiasi Merek

\begin{tabular}{lccc}
\hline \multicolumn{1}{c}{ Sub variabel } & Means & $\begin{array}{c}\text { Paired Differences } \\
\text { Means }\end{array}$ & Sig. (2-tiled) \\
\hline Nike Association & 4.12 & -0.20 & 0.022 \\
Adidas Association & 4.32 & & \\
\hline Sumber : Data primer diolah, 2018 & &
\end{tabular}

Tabel 15. menunjukkan bahwa rata-rata asosiasi merek produk olahraga merek Nike sebesar 4,12 dan rata-rata asosiasi merek produk olahraga merek Adidas sebesar 4,32. Hal ini berarti rata-rata asosiasi merek produk olahraga merek Nike lebih kecil dibandingkan dengan rata-rata asosiasi merek produk olahraga merek Adidas dengan perbandingan rata-ratanya sebesar 0,20. Probabilitasnya sebesar 0,022 yang berarti kurang dari sama dengan 0,05. Sehingga terdapat perbedaan yang signifikan antara asosiasi merek produk olahraga merek Nike dengan produk olahraga merek Adidas.

Tabel 15. juga menunjukkan bahwa asosiasi merek yang dimiliki merek Adidas lebih tinggi dari merek Nike menurut atlet Kota Denpasar. Atlet Kota Denpasar merasa bahwa produk olahraga merek Adidas lebih berhasil menciptakan asosiasi merek produknya jika dibandingkan dengan merek Nike. 
Perbedaan ini dapat dilihat dari manfaat, citra perusahaan, ketersediaan barang, maupun tampilan.

Nilai signifikansi pada asosiasi merek adalah sebesar 0,022 kurang dari sama dengan 0,05 maka kesimpulannya adalah $\mathrm{H}_{0}$ ditolak dan $\mathrm{H}_{2}$ diterima, ini berarti terdapat perbedaan signifikan asosiasi merek produk olahraga merek Nike dengan merek Adidas.

Tabel 16.

Uji Beda T-test Persepsi Kualitas

\begin{tabular}{lccc}
\hline \multicolumn{1}{c}{ Sub variabel } & Means & $\begin{array}{c}\text { Paired Differences } \\
\text { Means }\end{array}$ & Sig. (2-tiled) \\
\hline Nike Perceived & 4.19 & -0.30 & 0.00 \\
Adidas Perceived & 4.49 & &
\end{tabular}

Tabel 16. menunjukkan bahwa rata-rata persepsi kualitas produk olahraga merek Nike sebesar 4,19 dan rata-rata persepsi kualitas produk olahraga merek Adidas sebesar 4,49. Hal ini berarti rata-rata persepsi kualitas produk olahraga merek Nike lebih kecil dibandingkan dengan rata-rata persepsi kualitas produk olahraga merek Adidas dengan perbandingan rata-ratanya sebesar 0,30. Probabilitasnya sebesar 0,00 yang berarti kurang dari sama dengan 0,05 . Sehingga terdapat perbedaan yang signifikan antara persepsi kualitas produk olahraga merek Nike dengan produk olahraga merek Adidas. Dilihat dari rata-rata persepsi kualitas merek, Adidas menghasilkan nilai rata-rata yang lebih tinggi dari merek Nike. Atlet Kota Denpasar menganggap kualitas, harga yang relevan, maupun daya tahan atau tingkat kenyamanan produk olahraga merek Adidas lebih baik dari merek Nike.

Nilai signifikansi pada persepsi kualitas adalah sebesar 0,00 kurang dari sama dengan 0,05 maka kesimpulannya adalah $\mathrm{H}_{0}$ ditolak dan $\mathrm{H}_{3}$ diterima, ini berarti terdapat perbedaan signifikan persepsi kualitas produk olahraga merek Nike dengan merek Adidas.

Tabel 17.

Uji Beda T-test loyalitas merek

\begin{tabular}{lccc}
\hline \multicolumn{1}{c}{ Sub variabel } & Means & $\begin{array}{c}\text { Paired Differences } \\
\text { Means }\end{array}$ & Sig. (2-tiled) \\
\hline Nike Loyalty & 4.17 & -0.33 & 0.00 \\
Adidas Loyalty & 4.50 & &
\end{tabular}

Tabel 17. menunjukkan bahwa rata-rata loyalitas merek produk olahraga merek Nike sebesar 4,17 dan rata-rata loyalitas merek produk olahraga merek Adidas sebesar 4,50. Hal ini berarti rata-rata persepsi kualitas produk olahraga merek Nike lebih kecil dibandingkan dengan rata-rata persepsi kualitas produk olahraga merek Adidas dengan perbandingan rata-ratanya sebesar 0,33.

Probabilitasnya sebesar 0,00 yang berarti kurang dari sama dengan 0,05 . Sehingga terdapat perbedaan yang signifikan antara loyalitas merek produk olahraga merek Nike dengan produk olahraga merek Adidas. Dilihat dari nilai 
rata-rata loyalitas merek, produk olahraga merek Adidas lebih besar dibandingkan merek Nike dengan demikian atlet Kota Denpasar menilai bahwa mereka memiliki tingkat kesetiaan yang lebih tinggi terhadap produk olahraga merek Adidas dibandingkan dengan merek Nike. Hal ini dikarenakan produk olahraga merek Adidas dianggap memiliki kualitas dan tingkat kenyamanan yang lebih baik ketika digunakan berlatih dibandingkan produk olahraga merek Nike. Selain itu model yang bervariasi dan harga yang sesuai dengan kualitas yang diberikan juga memiliki pengaruh terhadap kesetiaan.

Nilai signifikansi pada persepsi kualitas adalah sebesar 0,00 kurang dari sama dengan 0,05 maka kesimpulannya adalah $\mathrm{H}_{0}$ ditolak dan $\mathrm{H}_{4}$ diterima, ini berarti terdapat perbedaan signifikan loyalitas merek produk olahraga merek Nike dengan merek Adidas.

Implikasi dari penelitian ini mencakup dua hal yaitu, implikasi teoretis dan implikasi praktis. Implikasi teoretis berhubungan dengan kontribusinya bagi perkembangan teori mengenai variabel brand equity dan elemen-elemen yang terdapat didalamnya yaitu kesadaran merek, asosiasi merek, persepsi kualitas dan loyalitas merek. Sedangkan implikasi praktis berkaitan dengan kontribusi penelitian terhadap peningkatan nilai merek bagi perusahaan-perusahaan yang bergerak dalam bisnis produk olahraga bermerek, khususnya merek Nike dan merek Adidas.

Berdasarkan penelitian yang telah dilakukan dapat diketahui bahwa secara teoretis, penelitian ini secara keseluruhan mendukung beberapa teori brand equity yang telah ada sebelumnya. Penelitian ini diharapkan dapat menjadi wacana baru untuk penelitian yang berhubungan dengan analisis elemen-elemen brand equity.

Pengolahan data dilakukan dengan uji beda t-test sampel berpasangan (paired sample). Uji beda t-test dilakukan untuk mengetahui tentang ada tidaknya perbedaan yang signifikan antara kedua kelompok sampel dengan jalan perbedaan rata-rata (mean). Hasil penelitian ini diharapkan dapat digunakan untuk memperkaya referensi dan ilmu pengetahuan yang berkaitan dengan brand equity beserta keempat elemennya.

Hasil penelitian ini diharapkan dapat menjadi referensi bagi perusahaan Nike dan Adidas untuk memperkuat brand equity masing-masing merek. Brand equity yang kuat dapat mempertinggi keberhasilan program dalam memikat konsumen baru atau merangkul kembali konsumen lama. Empat dimensi dari brand equity dapat memengaruhi konsumen untuk melakukan pembelian, apabila salah satu dimensi tidak kuat dalam memengaruhi konsumen maka ketiga dimensi lainnya dapat menjadi rangsangan bagi konsumen untuk tidak mencoba merek tersebut. Berdasarkan hasil penelitian ini, didapatkan hasil bahwa rata-rata terdapat perbedaan elemen brand equity pada produk olahraga merek Nike dengan merek Adidas.

Pada perbandingan kesadaran merek, atlet Kota Denpasar lebih sadar akan keberadaan produk olahraga merek Adidas karena memiliki tampilan atau model yang lebih menarik dibandingkan produk olahraga merek Nike. Pada perbandingan asosiasi merek, atlet Kota Denpasar menganggap faktor tingkat ketersediaan atau distribusi merek Adidas lebih mudah ditemui dibandingkan denga merek Nike. 
Pada elemen persepsi kualitas, produk olahraga merek Adidas lebih mendekati harapan atlet Kota Denpasar dari segi kualitas, tingkat kenyamanan dan kesesuaian harga dibandingkan produk olaharga merek Nike. Lalu pada elemen loyalitas merek atlet Kota Denpasar merasa lebih komit atau setia pada produk olahraga merek Adidas dibandingkan merek Nike. Hasil penelitian sesuai dengan pernyataan-pernyataan pada kuesioner menunjukkan bahwa penilaian atlet Kota Denpasar terhadap kedua merek termasuk dalam kategori baik.

Patut disadari bahwa terdapat beberapa keterbatasan dari penelitian ini yang diantaranya : Keterbatasan ruang dan variabel penelitian, di mana dalam penelitian ini hanya menggunakan variabel kesadaran merek, asosiasi merek, persepsi kualitas, dan loyalitas merek.Penelitian ini hanya dilakukan di Kota Denpasar sehingga hasil penelitian ini tidak dapat digeneralisasi untuk atlet di luar wilayah Kota Denpasar. Produk yang diteliti dalam penelitian ini menyasar segmen tertentu saja yaitu atlet sehingga tidak dapat menjangkau semua responden. Sebaiknya, kedepannya penelitian dilakukan dengan responden yang lebih beragam sehingga akan memberikan gambaran hasil penelitian yang lebih beragam juga.

\section{SIMPULAN}

Simpulan yang dapat diberikan berdasarkan pembahasan hasil penelitian yang telah dilakukan, sebagai berikut: Terdapat perbedaan signifikan kesadaran merek produk olahraga merek Nike dengan merek Adidas. Hal ini menunjukkan bahwa salah satu faktor yang menyebabkan adanya perbedaan kesadaran merek ini yaitu adanya perbedaan kemunculan kedua merek di benak konsumen ketika hendak membeli produk olahraga.Terdapat perbedaan signifikan asosiasi merek produk olahraga merek Nike dengan merek Adidas. Hal ini menunjukkan bahwa faktor yang menyebabkan adanya perbedaan asosiasi merek ini yaitu adanya perbedaan desain, ketersediaan, dan diproduksi oleh perusahaan dengan reputasi yang berbeda. Terdapat perbedaan signifikan persepsi kualitas produk olahraga merek Nike dengan merek Adidas. Hal ini menunjukkan bahwa salah satu faktor yang menyebabkan adanya perbedaan persepsi kualitas yaitu perbedaan kualitas, harga serta tingkat kenyamanan saat dipakai. Terdapat perbedaan signifikan loyalitas merek produk olahraga merek Nike dengan merek Adidas. Hal ini menunjukkan bahwa faktor loyalitas merek dipengaruhi oleh ketiga elemen sebelumnya yaitu kesadaran merek, asosiasi merek dan persepsi kualitas. Konsumen akan merasa loyal apabila brand equity masing-masing merek sudah mampu memenuhi harapan konsumen atau memberikan kepuasan.

Saran yang dapat diberikan berdasarkan simpulan yang dipaparkan kepada perusahaan dan peneliti selanjutnya, sebagai berikut : Penelitian ini dilakukan dalam kurun waktu kurang dari setahun dan perubahan pola latihan atlet mungkin akan berubah yang berdampak pada pembelian produk olahraga, sehingga bisa dilakukan penelitian lanjutan seiring berubahnya waktu dan tingkat konsumsi atlet dalam membeli produk olahraga. Dikarenakan penelitian ini hanya dilakukan pada atlet Kota Denpasar, diharapkan penelitian selanjutnya bisa dilakukan pada atlet Provinsi Bali dengan ruang lingkup yang lebih luas. 
Perusahaan Nike dan Adidas diharapkan mampu meningkatkan elemen kesadaran merek melalui iklan atau media lainnya untuk membuat atlet tetap sadar akan keberadaan kedua merek produk olahraga tersebut. Perusahaan Nike dan Adidas diharapkan mampu meningkatkan elemen asosiasi merek dengan menciptakan desain produk menjadi lebih menarik dan bervariasi sehingga atlet akan merasa tertarik untuk melakukan pembelian lagi. Perusahaan Nike dan Adidas diharapkan mampu meningkatkan elemen persepsi kualitas dengan menjaga kualitas dan performa produk olahraga agar memberikan rasa nyaman saat digunakan oleh atlet. Perusahaan Nike dan Adidas diharapkan mampu meningkatkan elemen loyalitas merek dengan membuat konsumen merasa puas dan memenuhi harapan-harapan konsumen sehingga akan tercipta loyalitas atau kesetiaan.

\section{REFERENSI}

Alam, W., Saeed, T., \& Malik, Z. K. (2016). Role of Brand Image on Brand Equity: A Comparative Study of Public and Private Sector HIigher Education Institution of Khyber Pakhtunkhwa. City University Research Journal, 6(1), 48-60.

Chen, H.-C., \& Green, R. D. (2012). Brand Equity, Marketing Strategy, And Consumer Income: A Hypermarket Study. International Business \& Economics Research Journal, 11(2), 1-18.

Darmawan, H., \& Syarifah, A. (2016). Perbandingan Ekuitas Merek Indomie dan Mie Sedaap. Jurnal Manajemen Fakultas Ekonomi Dan Bisnis Universitas Mulawarman, 8(2), 113-135.

Dewi, M. M. (2017). Pengaruh Brand Awareness, Perceived Quality of Brand, Brand Association, Brand Loyalty, dan Brand Image Terhadap Brand Equity Erigo MenurutMahasiswa di Surabaya. Calyptra: Jurnal Ilmiah Mahasiswa Universitas Surabaya, 6(2), 825-842.

Fayrene, \& Lee, G. C. (2011). Customer-based Brand Equity: A Literature Review. Journal of Arts Science \& Commerce, 11(1), 33-42.

Garlina, Y. H. (2014). Comparison of Skin Moisturizer: Consumer-Based Brand Equity (Cbbe) Factors In Clusters Based On Consumer Ethnocentrism. Journal The Winners, 15(2), 115-122.

Huang, C.-C., Yen, S.-W., \& Liu, C.-Y. (2014). The Relationship Among Brand Equity, Costumer Satisfaction, and Brand Resonance to Repurchase Intentionof Culturaland Creative Industries in Taiwan. International Journal of Organizational Innovation, 6(3), 106-121.

Idris, I., Hanum, Z., \& Wahyudi, D. (2015). Analisis Ekuitas Merek Ponsel Samsung Sebagi Usulan Untuk Membidik Segmentasi Baru Di Kota Medan. Jurnal Bisnis Administrasi, 4(2), 75-78. 
Maulidina, R., \& Ariyanti, M. (2016). Analisis Ekuitas Merek Smartphone Apple dan Samsung Pada Konsumen Muda di Indonesia (Kesadaran Merek, Persepsi Kualitas, Asosiasi Merek, dan Loyalitas Merek). Management Analysis Journal, 3(2), 1113-1119.

Mirhan, \& Jusuf, J. B. K. (2016). Hubungan Antara Percaya Diri dan Kerja Keras Dalam Olahraga dan Keterampilan Hidup. Jurnal Olahraga Prestasi, 12(1), 86-96.

Nainggolan, M. (2018). Analisis Perbandingan Ekuitas Merek Kartu Seluler Merek SimPATI dan XL Prabayar. Jurnal Digest Marketing, 3(1), 1-6.

Nor, H., Abidin, N., \& Borhan, H. B. (2016). Perceived Quality and Emotional Value That Influence Costumer's Purchase Intention Towards American and Local Product. Economic and Finance, 3(5), 639-643.

Omer, K. T. (2014). Audience-Based Brand Equity: A Research on Women's Tennis Association Championships Istanbul 2013. International Business Research, 7(9), 141-156.

Pinar, M., Girald, T., \& Eser, Z. (2012). Consumer-Based Brand Equity In Banking Industry. International Journal of Bank Marketing, 30(5), 359-375.

Pramana, P., \& Aksari, A. (2018). Analisis Perbandingan Brand Equity Produk Indocafe dengan Good Day di Kota Denpasar. E-Jurnal Manajemen Unud, 7(9), 5080-5107.

Sasmita, J., \& Suki, N. M. (2015). Young Consumers' Insights On Brand Equity. International Journal of Retail \& Distribution Management, 4(3), 276-292.

Severi, E., \& Ling, K. C. (2013). The Mediating Effects Of Brand Association, Brand Loyalty, Brand Image, And Perceived Quality On Brand Equity. Asian Social Science, 9(3), 125-137.

Shabbir, C. P. R., \& Jing, Z. (2014). The Relationship of Brand Equity Dimension: A Casestudy Of Samsung Brand in Thailand. European Journal of Business and Management, 6(1), 182-189.

Shahin, A., Kazemi, A., \& Mahyari, H. K. (2012). How Consumer's Perception of Country of Country of Origin Affects Brand Equity: A Case Study in Iran Middle-East. Journal of Scientific Research, 12(6), 8-10.

Shamma, \& Hasan, S. . (2011). Integrating Product and Corporate Brand Equity Into Total Brand Measurement. International Journal of Marketing Studies, $3(1), 1-10$.

Sigiro, A. C., Putri, Y. R., \& Imran, A. I. (2016). Analisis Faktor Pembentuk Ekuitas Merek Toyota dan Daihatsu di Indonesia. Jurnal Sosioteknologi, 15(3), 335-345.

Silaban, B., \& Marselia, F. A. (2016). Perbandingan Ekuitas Merek Sepatu Olahraga Nikedan Adidas. Journal of ESENSI, 19(2), 88-111. 
Tan, T. M., Liew, T. W., William, L. S. S., Michelle, O. B. F., \& Tan, S.-M. (2012). Consumer-Based Brand Equity In The Service Shop. International Journal of Marketing Studies, 4(4), 60-77.

Tong, X., \& Hawley, J. . (2009). Measuring Costumer-based Brand Equity: Empirical Evidence From The Sportsware Market in China. Journal of Product \& Brand Management, 18(4), 262-271.

Utami, D. (2015). Peran Fisiologi Dalam Meningkatkan Prestasi Olahraga Indonesia Menuju Sea Games. Jurnal Olahraga Prestasi, 11(2), 52-63. 